\title{
At-a-glance
}

\section{Emergency department presentations for hoverboard-related injuries: the electronic Canadian Hospitals Injury Reporting and Prevention Program, 2015 to 2016}

\author{
M. T. Do, PhD (1,2); S. McFaull, MSc (1); J. Cheesman (1); T. Mersereau, MSc (3); D. P. Rao, PhD (1); J. Crain, MA (1); \\ W. Thompson, MSc (1)
}

\section{Introduction}

The Canadian Hospitals Injury Reporting and Prevention Program (CHIRPP) ${ }^{1}$ is an emergency department-based injury and poisoning surveillance system established in 1990 in response to the need for enhanced and timelier injury surveillance information in Canada. The CHIRPP currently operates in 11 pediatric and six general hospitals across Canada and is funded and administered by the Public Health Agency of Canada. The purpose of this report is to provide an overview of hoverboard-related injuries reported to CHIRPP's electronic system (eCHIRPP) as of July 7, 2016.

\section{Methods}

A hoverboard is a battery-powered, handsfree, self-balancing two-wheeled vehicle similar to a skateboard, capable of travelling up to $20 \mathrm{~km} /$ hour. We conducted a search of narratives within the eCHIRPP database for hoverboard-related injuries on July 7, 2016. Reported events were searched for in the injury event description field using the phrases "hover" and "self" + "balanc" + "scooter". For completeness, additional terms were also considered (e.g. "swagway”, "segway”, "planche de hover" and "hover planche"). We conducted manual resolution to ensure accuracy and precision of identified events.

\section{Results}

The first hoverboard-related injury reported through eCHIRPP was in October 2015. As of July 7, 2016, 35 cases have been recorded in eCHIRPP (Table 1). Cases were equally distributed among males and females. The average age at injury was 12.7 years (SD 5.0). Most of the injuries $(\mathrm{N}=20)$ resulted in a fracture involving the upper arm, elbow, forearm or wrist (Table 2). Of the 35 reported cases, 19 required treatment in the emergency department and further follow-up. The majority of the injuries occurred indoors $(\mathrm{N}=23)$ and in December and January.

\section{Discussion}

Hoverboards, a consumer product, were introduced to the Canadian market in June 2015. Our search revealed that most hoverboard use took place close to the holiday season. While our data did not show fires or explosions related to hoverboard batteries as observed in the United States, ${ }^{2}$ it is surprising to find a significant proportion of the hoverboards were being used indoors. Their use in confined areas should therefore be avoided, as malfunctioning hoverboards may present a fire hazard. In addition, the use of proper safety gear when riding, including a helmet, knee pads, elbow pads, and wrist guards, is recommended. This will lower the risk of fractures, sprains and other injuries if there is a fall.

\section{Limitations}

It is important to note that our sample is not fully representative of the Canadian population. In addition to older teens and adults, Aboriginal persons and people who live in rural areas are also underrepresented in the eCHIRPP database,

\section{Tweet this article}

TABLE 1

Characteristics of injuries related to hoverboards

\begin{tabular}{|c|c|}
\hline Characteristics & Counts \\
\hline \multicolumn{2}{|l|}{ Gender } \\
\hline Male & 18 \\
\hline Female & 17 \\
\hline \multicolumn{2}{|l|}{ Age (yrs) } \\
\hline $5-9$ & 6 \\
\hline $10-14$ & 26 \\
\hline $15-19$ & 2 \\
\hline $30-39$ & 1 \\
\hline Mean (SD) & $12.7(5.0)$ \\
\hline \multicolumn{2}{|l|}{ Place of injury } \\
\hline Indoor & 23 \\
\hline Outdoor & 10 \\
\hline Missing & 2 \\
\hline \multicolumn{2}{|l|}{ Area } \\
\hline Bedroom & 2 \\
\hline Hall, foyer & 3 \\
\hline Kitchen & 2 \\
\hline Dining area, cafeteria & 1 \\
\hline $\begin{array}{l}\text { Living room, family room, } \\
\text { recreation room }\end{array}$ & 5 \\
\hline Basement, cellar & 7 \\
\hline Roadway, paved & 2 \\
\hline Driveway & 1 \\
\hline Sidewalk, path, bus stop & 2 \\
\hline Garden, yard & 4 \\
\hline Unknown area & 6 \\
\hline
\end{tabular}

Abbreviation: SD, standard deviation. 
TABLE 2

Injury characteristics

\begin{tabular}{|c|c|}
\hline Characteristics & Counts \\
\hline \multicolumn{2}{|l|}{ Nature of injury } \\
\hline $\begin{array}{l}\text { Superficial, including bruises, } \\
\text { abrasions }\end{array}$ & 2 \\
\hline $\begin{array}{l}\text { Open wound, including minor cuts, } \\
\text { lacerations }\end{array}$ & 1 \\
\hline Fracture & 20 \\
\hline $\begin{array}{l}\text { Dislocation, including subluxation, } \\
\text { spine }\end{array}$ & 2 \\
\hline $\begin{array}{l}\text { Sprain or strain, including upper and } \\
\text { lower back }\end{array}$ & 2 \\
\hline Soft tissue injury NFS & 5 \\
\hline Minor closed head injury & 1 \\
\hline Concussion & 2 \\
\hline \multicolumn{2}{|l|}{ Body part } \\
\hline Head injury & 3 \\
\hline Lower back & 1 \\
\hline Shoulder, including scapula & 1 \\
\hline Upper arm, including humerus & 1 \\
\hline Elbow & 4 \\
\hline Forearm, including radius, ulna & 9 \\
\hline Wrist, including carpal bones & 5 \\
\hline Hand, including metacarpals & 1 \\
\hline Finger or thumb & 4 \\
\hline Knee, including patella & 2 \\
\hline Ankle, including tarsal bones & 1 \\
\hline Toe & 3 \\
\hline \multicolumn{2}{|l|}{ Disposition } \\
\hline $\begin{array}{l}\text { Advice only, diagnostic testing, } \\
\text { referred to GP (no treatment in ED) }\end{array}$ & 7 \\
\hline Treated in ED with follow-up PRN & 6 \\
\hline Observation in ED, follow-up PRN & 1 \\
\hline Observation in ED, follow-up required & 2 \\
\hline Treated in ED, follow-up required & 19 \\
\hline
\end{tabular}

Abbreviations: BP, body part; ED, emergency department; GP, general practitioner; NFS, not further specified; PRN, pro re nata (as needed). because most CHIRPP sites are pediatric hospitals located in major cities. Fatal injuries are also underrepresented in the eCHIRPP database because the emergency department data do not include people who died before they could be taken to hospital or those who died after being admitted.

\section{References}

1. Crain J, McFaull S, Thompson W, et al. Status report - The Canadian Hospitals Injury Reporting and Prevention Program: a dynamic and innovative injury surveillance system. Health Promot Chronic Dis Prev Can. 2016; 36(6):112-7.

2. US Consumer Product Safety Commission (CPSC). Self-balancing scooters/hoverboards recalled by 10 firms due to fire hazard [Internet]. Bethesda (MD): CPSC; 2016 [cited 2016 Jul 12]. Available from: http:// www.cpsc.gov/en/Recalls/2016/Self -Balancing-Scooters-Hoverboards -Recalled-by-10-Firms/ 